\title{
ROYALTY FEE BISNIS WARALABA RITEL DI KOTA MAKASSAR DALAM PERSPEKTIF HUKUM EKONOMI SYARIAH
}

\section{ROYALTY FEE OF RETAIL FRANCHISE BUSINESS IN THE CITY OF MAKASSAR AT PERSPECTIVE OF SHARIA ECONOMIC LAW}

\author{
Andi Nur Afifah \\ Sekolah Tinggi Ilmu Islam dan Bahasa Arab (STIBA) Makassar \\ Email: afifahstiba@gmail.com \\ Sohrah \\ Universitas Islam Negeri (UIN) Alauddin Makassar \\ Email: sohrah.uinalauddin@gmail.com \\ Muslimin Kara \\ Universitas Islam Negeri (UIN) Alauddin Makassar \\ Email: muslimin.kara@uin-alauddin.ac.id
}

\begin{abstract}
Keywords : ABSTRACT

royalty fee, franchise, retail store franchise bussines

The aim of this research was to determine and understand the royalty fees for retail store franchise business in the perspective of Islamic economic law in the city of Makassar. This research was a type of qualitative descriptive research (non-statistical) using normative, phenomenological, and sociological approaches. Findings of this research revealed that: First, the franchise of company $X$ with its franchisee was in accordance with the Islamic law, there was no element of fraud in terms of contracts and agreements which was implemented in transparency. While, the franchise of company $Y$ and its franchisee, there were different perceptions of policies related to the contract and franchise agreement, namely the absence of a written signing so that it was not in accordance with sharia, but both parties agreed on considerations and amendment policies that made specifically by the franchisee. Second, the implementation of royalty fees between the two companies had been carried out in transparency. The difference of both companies and their franchisees was from the policy of late payment of royalty fees. Company $X$ and its franchisee used a maximum three-month deadline with an interest system, this was not adjusted to Islamic law because interest includes usury. Then, company $Y$ and its franchisee would absolutely not use the delay system policy, because the royalty fee would automatically be deducted from the franchisee's cashback by purchasing products at Company Y.

Kata kunci :

\section{ABSTRAK}

\section{biaya royalti, waralaba,} bisnis waralaba toko ritel
Penelitian ini bertujuan untuk mengetahui dan memahami royalty fee bisnis waralaba toko ritel dalam perspektif hukum ekonomi syariah di kota Makassar. Penelitian ini merupakan jenis penelitian deskriktif kualitatif (non-statistik) menggunakan metode pendekatan normatif, fenomenologis, dan sosiologis. Hasil penelitian menemukan; Pertama, waralaba Perusahaan X dengan 


\begin{abstract}
franchiseenya sudah sesuai dengan syariat hukum Islam, yakni tidak adanya unsur kecurangan dari segi akad dan perjanjian serta dilakukan secara transparansi, adapun Perusahaan $\mathrm{Y}$ dengan franchiseenya, ada perbedaan persepsi kebijakan terkait akad dan perjanjian waralabanya, yakni belum adanya penandatanganan tertulis sehingga tidak sesuai dengan syariat, tetapi kedua belah pihak sama-sama menyepakati pertimbangan dan kebijakan amandemen yang dibuat khusus oleh franchisee-nya. Kedua, implementasi royalty fee antara kedua perusahaan tersebut sudah dilakukan secara transparansi, yang membedakan dari keduanya dari kebijakan keterlambatan pembayaran royalty fee, Perusahaan X dengan franchisee-nya menggunakan tenggat waktu tiga bulan maksimal dengan sistem bunga, hal ini tidak disesuaikan dengan syariat Islam karena bunga termasuk riba, selanjutnya Perusahaan Y dengan franchisee-nya sama sekali tidak akan menggunakan kebijakan sistem keterlambatan, karena royalty fee otomatis akan dipotong dari cashback franchisee-nya dengan pembelian produk di Perusahaan Y tersebut.
\end{abstract}

Diterima: 31 Maret 2021; Direvisi: 1 Juni 2021; Disetujui: 1 Juni 2021; Tersedia online: 11 Juni 2021

How to cite: Andi Nur Afifah, Sohra dan Muslimin Kara. "Royalty Fee Bisnis Waralaba Ritel di Kota Makassar dalam Perspektif Hukum Ekonomi Syariah.” NUKHBATUL 'ULUM: Jurnal Bidang Kajian Islam 7, no. 1 (2021): 139-158. https://doi.org/10.36701//nukhbah.v7i1.296.

\title{
PENDAHULUAN
}

Salah satu aspek cakupan ajaran Islam yang sejak awal telah menjadi diskursus al-Qur'an adalah masalah kegiatan ekonomi dalam kehidupan umat manusia. Al-Qur'an lahir tidak dalam lingkungan hampa, tetapi dalam realita manusia yang kompleks termasuk persoalan-persoalan ekonomi manusia. Berbagai respon Islam terhadap praktik-praktik perniagaan yang dilakukan oleh sebagian masyarakat Makkah pada awal kelahirannya dan contoh-contoh kegiatan ekonomi yang dilakukan oleh Nabi Muhammad saw. beserta para sahabatnya di Makkah dan Madinah, menunjukkan bahwa Islam sejak awal kemunculannya telah menunjukkan bukti perhatiannya terhadap kegiatan ekonomi. ${ }^{1}$

Salah satu praktik perniagaan bagi hasil yang sudah merebak luas dan menjadi kalangan tren di bisnis ritel atau perusahaan ialah bisnis waralaba. Waralaba dalam dunia bisnis terkenal dengan istilah "franchise", yaitu pemberian sebuah lisensi usaha oleh suatu pihak (perorangan atau perusahaan) kepada pihak lain sebagai penerima waralaba. Dengan kata lain, waralaba adalah pengaturan bisnis dengan sistem pemberian hak pemakaian nama dagang oleh pewaralaba kepada pihak terwaralaba untuk menjual produk atau jasa sesuai dengan standardisasi

\footnotetext{
${ }^{1}$ Sutan Remi Sjahdeni, Perbankan Syariah: Produk-Produk Dan Aspek-Aspek Hukumnya, 1st ed. (Jakarta: Kencana, 2014).
} 
kesepakatan untuk membuka usaha dengan menggunakan merk dagang/ nama dagangnya. $^{2}$

Franchise pada dasarnya adalah sebuah perjanjian mengenai metode pendistribusian barang dan jasa kepada konsumen. Franchisor dalam jangka waktu tertentu memberikan lisensi kepada franchisee untuk melakukan usaha pendistribusian barang dan jasa di bawah nama identitas franchisor dalam wilayah tertentu. Usaha tersebut harus dijalankan sesuai dengan prosedur dan cara yang ditetapkan franchisor. Franchisor memberikan bantuan terhadap franchisee sehingga franchisee membayar imbalan berupa initial fee maupun royalti.

Royalty fee jika dilihat dengan saksama, maka hasil usaha yang dikembangkan oleh franchisee di bawah franchisor akan mendapatkan semacam penghasilan bersih dan penghasilan kotor. Besaran royalty fee berbeda-beda, tergantung kebijakan setiap waralaba. Dari kedua penghasilan tersebut, maka sistem yang sudah terimplementasi dari royalty fee ini akan bekerja dan tersalurkan hasil keuntungannya pada merk atau brand sebagai imbalan dari nilai hak kekayaan intelektual. Konsep Islam dalam bermuamalah amat jelas, setiap individu bebas dalam membuat perjanjian yang belum ada ketentuannya dalam syariah, selama tidak bertentangan dengan syara' dan tidak pula bertentangan dengan hakikat perjanjian itu sendiri termasuk di dalamnya menentukan besaran royalty fee. Asalkan sepanjang kebebasan itu dapat dipertanggungjawabkan baik secara sosial maupun di hadapan Allah. ${ }^{3}$ Oleh karena itu kejelasan dan transparansi dalam memulai kontrak ketika membeli franchise sangat penting agar terlihat hak dan kewajiban antara franchisor dan franchisee, jangan sampai ada pihak yang menzalimi dan dizalimi. ${ }^{4}$

Setelah mengetahui seluk beluk proses bisnis waralaba terkhusus pada sistem royalty fee, maka penulis akan mengungkapkan sisi lain dari hukum Islamnya dalam hal ini dispesifikkan dalam studi analisis hukum ekonomi syariah, pihak terwaralaba telah membayar uang sewa hak intelektual dan berbagai layanan yang diberikan oleh pewaralaba (franchisor). Dengan demikian, seharusnya ia tidak lagi memungut bagi hasil bulanan dari keuntungan pihak terwaralaba. Adanya pungutan fee bulanan ini, menjadikan nominal nilai sewa hak-hak intelektualnya tidak jelas, atau yang disebut dengan gharar. Dan telah diketahui adanya gharar (ketidak-jelasan) pada suatu akad menjadikannya terlarang dalam syariat. Selain itu, ditinjau dari implementasi sistem royalty fee yang belum dijelaskan secara transparansi apakah sesuai dengan syariat Islam atau bertentangan.

Untuk menjawab beberapa permasalahan di atas, maka dapat dirumuskan beberapa tujuan dari penelitian ini sebagai berikut:

\footnotetext{
${ }^{2}$ Nistains Odop, Berbisnis Waralaba Murah (Yogyakarta: Media Pressindo, 2006).

${ }^{3}$ Budi Agus Riswadi, Hak Kekayaan Intelektual Dan Budaya Hukum (Jakarta: PT. Raja Grafindo Persada, 2004).

${ }^{4}$ Siti Najma, Bisnis Syariah Dari Nol; Langkah Jitu Menuju Kaya, Penuh Berkah Dan Bermakna (Jakarta: Hikmah, 2008).
} 
1. Bagaimana Penerapan Bisnis Waralaba Toko Ritel dalam Perspektif Hukum Ekonomi Syariah di beberapa toko ritel Makassar?

2. Bagaimana Sistem Royalty Fee Bisnis Waralaba Toko Ritel dalam Perspektif Hukum Ekonomi Syariah di beberapa toko ritel Makassar?

Untuk mendapatkan jawaban atas masalah tersebut, penulis menggunakan jenis penelitian deskriktif kualitatif (non-statistik) yang terfokus pada studi lapangan. Serta menggunakan metode pendekatan normatif, fenomenologis, dan sosiologis. Adapun dari pengamatan penulis telah ada beberapa pengkajian atau penelitian terkait Royalty Fee Waralaba di antaranya:

1. Gemala Dewi, Wirdyaningsih, dan Yeni Salma Barlinti (2013) pada bukunya yang berjudul: "Hukum Perikatan Islam di Indonesia". Buku ini berisikan tentang perkembangan ekonomi Islam di Indonesia serta konsep dasar hukum perikatan dalam Islam. Hal ini juga dilengkapi dengan analisis kasus dalam tataran riil bisnis, sehingga bukan hanya konsep dan teori yang dihadirkan, melainkan juga aplikasinya dalam berbagai transaksi bisnis. Contoh yang bisa diambil dari buku ini adalah bagaimana tinjauan hukum Islam terhadap transaksi bisnis modern terkhusus pada waralaba (franchising). ${ }^{5}$

2. Mardani (2014) pada bukunya yang berjudul: "Hukum Bisnis Syariah". Buku ini berisikan tentang bisnis syariah yang bentuk aktivitas bisnisnya tidak dibatasi pada jumlah atau kuantitas kepemilikan harta (barang/jasa) termasuk profitnya, namun dibatasi dengan cara perolehan dan pendayagunaan hartanya berdasarkan tata aturan halal dan haram. Buku ini juga menjelaskan secara gamblang bagaimana bekerja dan bisnis dalam pandangan Islam, hak, kepemilikian dan harta dalam pandangan Islam, kerja sama dalam bisnis syariah, perusahaan dengan prinsip syariah terfokus pada lembaga perbankan syariah, serta beberapa fatwa DSN dan peraturan yang berkaitan dengan operasional bisnis syariah di Indonesia serta doktrin fikih. ${ }^{6}$

3. Musthafa Dib al-Bugha (2009), dengan buku yang berjudul: "Fikih Islam Lengkap Penjelasan Hukum-hukum Islam Madzhab Syafi'i”. Buku ini terjemahan dari al-Tazhib fì Adillat Matan al-Gāyat wa al-Taqrīb alMasyhūr bi Matan Abi Syuja' fì al-Fiqh al-Syāfi'i yang merupakan salah satu kitab rujukan dalam mempelajari fikih syar'i. Buku ini membahas seluruh aspek dalam ilmu fikih di antaranya kitab taharah, kitab salat, zakat, puasa, haji, jual beli dan muamalat lainnya, faraidh dan wasiat, nikah, jinayat, hudud, jihad, perburuan dan penyembelihan, perlombaan dan memanah, sumpah dan nazar, serta pengadilan dan persaksian. Salah satu bab yang dibahas di buku ini ialah bab jual beli dan muamalat lainnya yang di mana berkaitan dengan hukum musyarakah (perkongsian). Kali ini ditinjau dalam

${ }^{5}$ Gemala Dewi, Hukum Perikatan Islam Di Indonesia, V (Jakarta: Kencana, 2018).

${ }^{6}$ Mardani, Hukum Bisnis Syariah (Jakarta: Prenada Media Group, 2014). 
fikih muamalahnya, maka diteliti dari dalil halal-haramnya atau batasanbatasan tentang musyarakah ini berdasarkan pendapat para ulama dan sumber syariat Islam: al-Qur'an dan sunnah. ${ }^{7}$

Menyikapi beberapa referensi yang terkait, dapat disimpulkan bahwa penulis saat ini melihat grafik toko ritel cabang yang meningkat pesat di kota Makassar, hal ini memacu banyaknya ketertarikan untuk menekuni bisnis franchise atau dalam hal ini pembelian merk. Maka dari itu, karena banyaknya ketertarikan dalam bisnis tersebut, perlu ditelaah lebih eksplisit mengenai sistem bagi hasil atau royalty fee tersebut yang merupakan ranah internal dan sensitif di perusahaan bisnis toko ritel tersebut.

\section{PEMBAHASAN}

\section{Penerapan Bisnis Waralaba Toko Ritel di Kota Makassar dalam Perspektif Hukum Ekonomi Syariah}

\section{A. Perusahaan $\mathbf{X}$}

Staf Legal yang bertugas dalam pelayanan pembukaan mitra kerjasama franchise Perusahaan X khusus region Makassar mengatakan bahwa pada dasarnya waralaba X sama dengan sistem waralaba lainnya, yakni melibatkan franchise fee, biaya pemasaran/marketing, dan royalty fee serta pembiayaan lainnya, yang membedakannya ialah aturan dan nominalnya. Di antara nominal yang disebutkan, ialah:

1. Investasi sebesar 350 juta

2. Franchise Fee sebesar 75 juta

3. Biaya Pemeliharaan Toko sebesar 15 juta

4. Royalty Fee sebesar 2,5\% (setiap bulan)

5. Management Fee sebesar $1 \%$ (setiap bulan)

Isi kontrak bisnis waralaba yang menyangkut pemberian lisensi atau izin dari pemberi kepada penerima waralaba untuk memanfaatkan hak kekayaan intelektual di dalam menjalankan usaha bisnisnya masuk dalam kategori akad ijarah, agar sesuai dengan syarat sah akad ijarah, terdapat unsur-unsur sebagai berikut: ${ }^{8}$

1. Kontrak waralaba berupa perjanjian tertulis.

2. Hak Kekayaan Intelektual yang digunakan penerima waralaba dalam menjalankan usaha bisnisnya tidak lain adalah untuk mengambil manfaatnya, yaitu meningkatkan daya beli atau volume penjualan barang atau jasa.

\footnotetext{
${ }^{7}$ Musthafa Dib Al Bugha, Fikih Islam Lengkap Penjelasan Hukum-Hukum Islam Madzhab Syafi'i (Media Zikir, 2010).

${ }^{8}$ Oktofan Hari Yudanto, "Analisis Perjanjian Usaha Waralaba Makanan Dalam Perspektif Hukum Islam (Studi Kasus Di Crunchy Molen Kress Di Desa Gumpang. Kec. Kartasura, Kab. Sukoharjo),” Publikasi Ilmiah, 2017.
} 
3. Dalam bisnis waralaba, franchisee fee ditentukan nominal rupiah untuk jangka waktu tertentu.

4. Dalam bisnis waralaba, penggunaan manfaat atas Hak Kekayaan Intelektual oleh penerima waralaba.

5. Jika jangka waktu kontrak waralaba berakhir, pihak penerima waralaba mengembalikan seluruh data, informasi maupun keterangan yang berkenaan Hak Kekayaan Intlektual, penemuan atau ciri khas usaha seperti sistem manajemen, cara penjualan dan sebagainya yang menjadi obyek waralaba kepada pemberi waralaba.

Staf Legal mengatakan bahwasanya untuk perjanjian kerjasama Perusahaan X Region Makassar, semuanya dilakukan secara tertulis dengan mempertimbangkan syarat-syarat berikut:

1. Pertemuan antara pemberi waralaba dan penerima waralaba

2. Survei lokasi yang akan dijadikan target pasar mereka

3. Setelah keduanya sudah bersepakat, maka penerima waralaba menandatangani surat perjanjian dengan beberapa pasal-pasal yang sudah ditetapkan oleh Perusahaan X

4. Penerima waralaba dianggap sudah menyetujui semua pembiayaan yang harus dibayar, dan sukarela satu sama lain

5. Pemberi waralaba menyuplai produk-produk yang akan dijualbelikan. Beberapa pertimbangan juga diterima dari permintaan penerima waralaba jika ingin menjual produk lain di luar Perusahaan $\mathrm{X}$, hal itu diperbolehkan selama tidak bertentangan

6. Adanya pembicaraan yang transparansi antara penerima waralaba dan pemberi waralaba terkait bagi hasil nantinya

7. Selanjutnya penerima waralaba menggunakan hak sepenuhnya atas toko ritel Perusahaan $\mathrm{X}$ yang sudah didirikan, pemberi waralaba tinggal menunggu royalty fee yang disetor setiap bulannya

\section{B. Perusahaan $\mathbf{Y}$}

Sesuai dengan wawancara yang ditujukan kepada Perusahaan Y adalah bisnis retail minimarket yang dijalankan melalui kerjasama waralaba, di mana pihak pewaralaba (pemegang merk) bekerjasama dengan terwaralaba (investor), dan dituangkan dalam bentuk perjanjian waralaba Perusahaan Y. Keuntungan dan kelebihan waralaba Perusahaan Y:

1. Nama toko menggunakan nama sendiri yang ditentukan pemilik.

2. Jaminan pasokan barang dagangan.

3. Penataan toko dan pemajangan/display barang dagangan yang teratur rapi sesuai planogram.

4. Program promosi yang berkesinambungan. 
5. Mendapatkan pelatihan dan pengawasan, sehingga terwaralaba bisa mengelola bisnisnya secara mandiri.

6. Pengelolaan karyawan dan keuangan dilakukan pemilik.

7. Boleh menjual item barang diluar yang bisa disupply Indogrosir.

8. Transaksi penjualan bisa dilakukan secara kredit.

9. Tergabung dengan jaringan usaha yang besar dan modern. Serta memperoleh peminjaman software yang terintegrasi dengan sistem operasional minimarket meliputi: penjualan, pemesanan barang, serta penetapan harga jual.

Sistem waralaba Perusahaan Y sangat tepat bila dikembangkan dalam koperasi maupun perorangan, karena terwaralaba tidak lagi mengalami kesulitan dalam mengoperasikan tokonya. Di antara nominal yang disebutkan, ialah:

1. Investasi sebesar 120-300 juta

2. Franchise Fee sebesar 33 juta

3. Biaya Pemeliharaan Toko dikondisikan sesuai kebutuhan

4. Royalty Fee sebesar $2,5 \%$ (setiap bulan)

5. Management Fee sebesar 1\% (setiap bulan)

\section{Analisis Bisnis Waralaba Toko Ritel pada Perusahaan X dan Y dalam Hukum Ekonomi Syariah}

Dilihat dari sudut bentuk perjanjian yang diadakan dalam waralaba (franchise) dapat dikemukakan bahwa perjanjian itu sebenarnya merupakan pengembangan dari bentuk kerja sama (syirkah). Hal ini disebabkan karena dengan adanya perjanjian franchise itu, secara otomatis antara pemberi waralaba dengan penerima waralaba terbentuk hubungan kerja sama untuk waktu tertentu (sesuai dengan perjanjian). Kerjasama tersebut dimaksud untuk memperoleh keuntungan bagi kedua belah pihak. Dalam hal ini bisnis waralaba tergolong syirkah inan, yaitu kerja sama antara dua orang atau lebih dalam permodalan untuk melakukan suatu usaha bersama dengan cara membagi untung atau rugi sesuai dengan jumlah modal masing-masing ${ }^{9}$ dan keuntungan dengan sistem mudharabah atau bagi hasil.

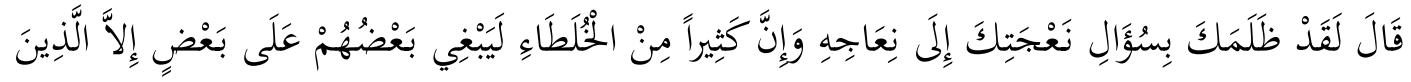

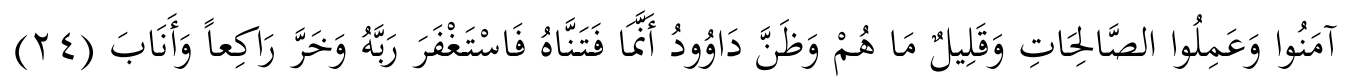

Terjemahannya:

Daud berkata: "Sesungguhnya Dia telah berbuat zalim kepadamu dengan meminta kambingmu itu untuk ditambahkan kepada kambingnya. dan Sesungguhnya kebanyakan dari orang-orang yang berserikat itu sebahagian mereka berbuat zalim kepada sebahagian yang lain, kecuali orang-orang yang beriman dan mengerjakan amal yang saleh; dan Amat sedikitlah mereka ini". dan Daud mengetahui bahwa Kami mengujinya; Maka ia meminta ampun kepada Tuhannya lalu menyungkur sujud dan bertaubat.

${ }^{9}$ Mardani, Fiqh Ekonomi Syariah (Jakarta: Kencana, 2013). 
Tafsir surat Shaad ayat 24, (Daud berkata, "Sesungguhnya dia telah berbuat lalim kepadamu dengan meminta kambingmu itu) dengan maksud untuk menggabungkannya (untuk ditambahkan kepada kambingnya. Sesungguhnya kebanyakan dari orang-orang yang berserikat itu) yakni orang-orang yang terlibat dalam satu perserikatan (sebagian mereka berbuat lalim kepada sebagian yang lain, kecuali orang-orang yang beriman dan mengerjakan amal yang saleh; dan amat sedikitlah mereka ini") huruf Ma di sini untuk mengukuhkan makna sedikit. Lalu kedua malaikat itu naik ke langit dalam keadaan berubah menjadi ujud aslinya seraya berkata, "Lelaki ini telah memutuskan perkara terhadap dirinya sendiri." Sehingga sadarlah Nabi Daud atas kekeliruannya itu. Lalu Allah berfirman, (Dan Daud yakin) yakni merasa yakin (bahwa Kami mengujinya) Kami menimpakan ujian kepadanya, berupa cobaan dalam bentuk cinta kepada perempuan itu (maka ia meminta ampun kepada Rabbnya lalu menyungkur rukuk) maksudnya bersujud (dan bertobat.). Ayat di atas menjelaskan bahwa maksud dari kata orang yang berpatungan ialah mereka yang bersyarikah. Sedangkan berlaku melampaui batas satu sama lain maknanya berlaku zhalim satu sama lain. Sehingga ayat ini menunjukkan bolehnya bersyarikah. Yang tidak boleh ialah berlaku zhalim atas sesama rekan patungan. Ayat di atas menjelaskan syirkah secara implisit bahwa orang yang berserikat atau berpatungan yang dimaksud adalah perkenaan dan pengakuan Allah terhadap bolehnya melakukan perserikatan dalam kepemilikan harta dimana hal ini menunjukkan perkongsian atau syirkah terjadi atas dasar akad (transaksi). ${ }^{10}$

Keberadaan waralaba dimungkinkan berdasarkan kaidah fiqhiyah yang bersifat umum yang berbunyi "segala sesuatu itu pada dasarnya boleh, kecuali kalau ada dalil yang mengharamkannya"11 atau kaidah fiqhiyah yang berbunyi "pada dasarnya pokok hukum terhadap akad dan muamalat itu hukumnya boleh (sah), sehingga ada dalil (syar'i) yang membatalkan atau mengharamkannya". ${ }^{12}$ Kaidah tersebut menjadi dasar hukum, bahwa ekonomi Islam bersifat terbuka, yang membolehkan para pihak untuk membuat perjanjian apa saja selama tidak ada dalil yang mengharamkan perjanjian tersebut.

Menurut penulis jika dikorelasikan dengan hukum Islam yang berlaku, sistem waralaba yang diterapkan pada Perusahaan X sudah memenuhi syarat dan rukun akad, yaitu adanya para pihak (franchisor dan franchisee), adanya obyek akad (barang yang diwaralabakan berupai produk-produk yang dijualkan dalam SOP toko ritel Perusahaan X), adanya sighat akad (ijab/ penawaran dan qabul/ penerimaan

\footnotetext{
${ }^{10}$ Abdullah bin Muhammad bin Abdurrahman bin Ishaq Al Syeikh, Tafsir Ibnu Katsir Jilid 2 (Bogor: Pustaka Imam Syafi'i, 2003).

${ }^{11}$ Aunur Rohim Faqih, “Kontrak Bisnis Syariah Studi Mengenai Penerapan Prinsip-Prinsip Syari'ah Dalam Pembiayaan Pada Bank Syariah Di Indonesia," 2014, 3.

${ }^{12}$ Muslim bin Muhammad bin Majid Addausry, al-Mumti' fi al-Qawā'id al-Fiqhiyyah (Saudi Arabia: Dār Zidni, 2007).
} 
yang sudah disetujui), dan adanya tujuan akad (terbebas dari khiyar). Sehingga aspek akad dalam bisnis waralaba di Perusahaan X ini sudah sah. Beliau mengatakan selama menjadi Staf Legal yang bertugas menjadi pembukaan franchise Perusahaan $\mathrm{X}$, tidak ada masalah yang terjadi ketika melakukan proses pembukaan outlet baru dalam artian semua penerima waralaba telah sepakat mengikuti aturan bisnis waralaba ini. Sebagaimana ditinjau dari aspek keadilan dan kerelaan satu sama lain yang dicantumkan dalam QS. An-Nisa/4: 29

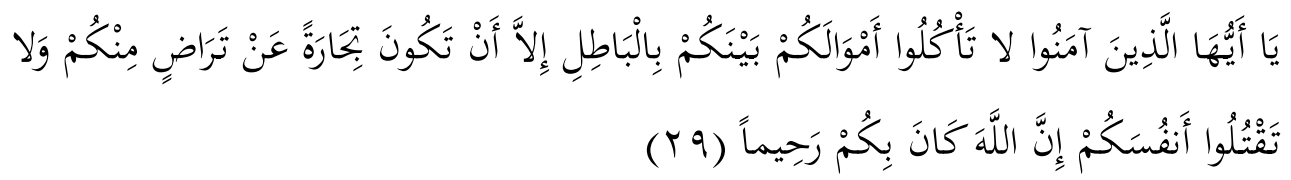

Terjemahannya:

Wahai orang-orang yang beriman! Janganlah kamu saling memakan harta sesamamu dengan jalan yang batil (tidak benar), kecuali dalam perdagangan yang berlaku atas dasar suka sama suka di antara kamu. Dan janganlah kamu membunuh dirimu. Sungguh, Allah Maha Penyayang kepadamu.

Allah swt. Melarang hamba-hamba-Nya yang beriman memakan harta sebagian mereka terhadap sebagian lainnya dengan batil, yaitu dengan berbagai macam usaha yang tidak syar'i seperti riba, judi, dan berbagai hal serupa yang penuh tipu daya, sekalipun pada lahiriahnya cara-cara tersebut berdasarkan keumuman hukum syar'i, tetapi diketahui oleh Allah dengan jelas bahwa pelakunya hendak melakukan tipu muslihat terhadap riba. Sehingga Ibnu Jarir berkata: "Diriwayatkan dari Ibnu Abbas tentang seseorang yang membeli baju dari orang lain dengan mengatakan jika anda senang, anda dapat mengambilnya, dan jika tidak, anda dapat mengembalikannya dan tambahkan satu dirham."

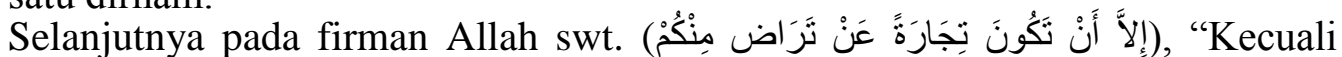
dengan perniagaan yang berlaku dengan suka sama suka." Lafazh Tijaarah dapat dibaca dengan rafa' atau nashab yaitu menjadi pengecualian terpisah. Seakan-akan Allah swt. berfirman: Janganlah kalian menjalankan (melakukan) sebab-sebab yang diharamkan dalam mencari harta, akan tetapi dengan perniagaan yang disyari'atkan, yang terjadi dengan saling meridhai antara penjual dan pembeli, maka lakukanlah hal itu dan jadikanlah hal itu sebagai sebab dalam memperoleh harta benda." 13

Dari penafsiran QS. Al-Nisa/4:29 bahwa bisa dijelaskan jual beli itu diperbolehkan selama masih dalam koridor syari'at, yakni saling rida satu sama lain sesuai dengan perjanjian yang disepakati. Kecuali jika dalam jual beli tersebut ada unsur yang bisa merugikan satu sama lain, maka hukum seperti ini tidak boleh. Saling merugikan satu sama lain bisa dikaitkan dengan riba, gharar, atau perjudian yang mana bukan hanya sebatas interaksi manusia tetapi masuk dalam perkara yang diharamkan oleh Allah swt. bahkan salah seorang ulama besar Imam Syafi'i berhujjah bahwa jual beli tidak sah kecuali dengan qabul (sikap menerima).

\footnotetext{
${ }^{13}$ Abdullah bin Muhammad bin Abdurrahman bin Ishaq Alu Syeikh, Lubaabut Tafsir Min Ibni Katsir (Pustaka Imam Asy Syafi'i, 2012).
} 
Berlanjut dari segi aspek keadilan dan kerelaan, maka penulis mengamati Perusahaan Y dan salah satu sampel toko cabangnya di Makassar, maka berdasarkan analisis hukum Islam, akad perjanjian perusahaan tersebut belum dianggap sah dalam hukum ekonomi syariah, hal ini bertentangan dengan QS. An-Nisa ayat 29, yakni prinsip kerelaan atas penandatangan kontrak kerjasama masih membutuhkan pertimbangan ulang dalam hal persentase royalty fee dan beberapa aturan lain yang sudah ditetapkan sehingga franchisee membuat beberapa aturan tersendiri, maka dari itu dapat disimpulkan adanya perbedaan keinginan di antara kedua belah pihak dan membuat sistem penandatangan kontrak terhambat, hal ini menyebabkan pemilik toko franchisee belum menandatangani kontrak perjanjian dikarenakan perbedaan pandangan dan konsepsi sistem, sementara pembayaran franchise fee sudah berjalan, maka usaha kerjasama antara franchisee dan Perusahaan Y selaku franchisor tetap berjalan, dan mau tak mau pihak Perusahaan Y memenuhi permintaan khusus terkait amandemen yang dibuat oleh franchisee.

Dari analisis hukum Islam, akad ini masuk kategori akad ghairu shahih fasid. Akad ghairu shahih fasid adalah akad yang yang sebagian unsur atau sebagian rukunnya tidak terpenuhi dan prinsipnya tidak bertentangan dengan syara' namun terdapat sifat-sifat tertentu yang dilarang oleh syara' yang dapat menyebabkan cacatnya irädah seperti adanya unsur paksaan. Sekalipun telah terjadi serah terima, pihak yang dirugikan dapat mengajukan fasakh atau pembatalan akad baik secara langsung maupun melalui qadhi (hakim), dengan syarat bendanya masih utuh sebagaimana adanya sebelum terjadi serah terima. Kedua, benda tersebut belum ditasharrufkan dengan pihak lain. Namun, antara franchisee dengan Perusahaan Y sendiri memiliki kebijakan tersendiri terhadap perbedaan konsepsi aturan waralaba ini, maka jika dianalisis kasus ini masuk dalam kategori khiyar lebih tepatnya khiyar majlis. ${ }^{14}$ Hasil dari pemaparan penjelasan narasumber bahwa kedua belah pihak, khiyar antara Perusahaan Y selaku franchisor dan franchisee-nya adalah tetap melangsungkan kontrak kerjasama dengan berbagai pertimbangan. Ada dua pendapat yang berbeda mengenai hukum khiyar majlis, pendapat pertama dipegang oleh mazhab Syafi'iyah dan Hanabilah yang mengatakan bahwasanya hukum khiyar ini sunnah atau diperbolehkan ${ }^{15}$, dan pendapat kedua yang dipegang oleh mazhab Malikiah dan Hanafiyah yang mengatakan bahwasanya khiyar majlis ini tidak ada dasarnya dalam syariah karena bertentangan dengan dalil al-Qur'an yaitu surah AlMa'idah/5: 1 dan An-Nisa/4: 29. Menurut mereka adanya ijab kabul dalam akad dipandang sudah memenuhi seluruh persyaratan akad didasarkan pada ayat tersebut. Karenanya kedudukan khiyar majlis dalam pandangan mereka sudah tidak dibutuhkan lagi mengingat posisi ijab kabul sebenarnya sudah mengandung unsur

\footnotetext{
${ }^{14}$ Wahbah Al Juhaily, Al Fiqh Al Islami Wa Adillatuhu (Beirut: Daar Al Fikr, 1989).

${ }^{15}$ Muhammad Fu'ad Abdul Baqi, Mutiara Hadis Yang Disepakati Bukhari Muslim (Al Lu'lu' Wal Marjan) (Surabaya: PT. Bina Ilmu, 2005).
} 
kerelaan dari masing-masing pihak yang melangsungkan transaksi. ${ }^{16}$ Dari kedua pendapat yang berbeda, maka penulis menyimpulkan bahwasanya pendapat kedua lebih disetujui yakni khiyar majlis tidak dibenarkan jika dikaitkan dengan akad penandatanganan kerjasama waralaba, karena Perusahaan $\mathrm{Y}$ dan franchisee-nya sudah melakukan transaksi franchise fee, sudah menyetujui beberapa aturan-aturan sesuai SOP Perusahaan Y, tetapi pada akhirnya franchisee-nya membuat amandemen khusus royalty fee dan beberapa aturan lainnya dengan dalih keberatan, maka akad perjanjian ini tidak sah dalam syariat hukum Islam.

Setelah menelisik prinsip keadilan dalam hukum ekonomi syariah, ada permasalahan baru yang masih perlu ditelisik secara implisit, yaitu produk-produk yang diperjualbelikan pada Perusahaan X. Dalam Perdagangan, kesepakatan dan kerelaan (adanya unsur suka sama suka) sangat ditekankan untuk dilaksanakan atau yang dikenal dengan sebutan antaradhin minkum. Hamzah Ya'qub mengemukakan bahwa,

Hanya dengan kesepakatan dan kerelaan yang berpangkal dari suka sama suka saja, tidak menjamin transaksi dapat dinyatakan sah dalam Islam yang mengatur adanya transaksi yang dibolehkan dan tidak dibolehkan, bahwa transaksi perdagangan dapat dikatakan tidak boleh (haram) jika masuk kedalam tiga kategori yang diharamkan, yaitu: Pertama, Perdagangan yang terlarang meliputi jenis barang atau zat; Kedua, Perdagangan yang terlarang meliputi segala usaha atau obyek dagangnya; Ketiga, Perdagangan yang terlarang meliputi cara-cara dagang atau jual beli yang terlarang. ${ }^{1}$

Dari segi perdagangan yang dilihat dari jenis dan zatnya terlarang untuk dilakukan, yaitu dengan melihat secara normatif yang terambil dari dasar hukum syar'i, walaupun dari segi akadnya perdagangan tersebut dipandang $\operatorname{sah}^{18}$, karena terpenuhinya seluruh unsur transaksi yang melingkupi adanya subyek, obyek dan akadnya, namun karena barang yang secara zatnya terlarang, maka ia akan menjadi haram untuk dilaksanakan oleh kaum Muslim. Barang yang disebutkan keharamannya dari segi zatnya yaitu diantaranya jual beli minuman keras, bangkai, daging babi, dan lainnya, sebagaimana yang dicontohkan oleh Adiwarman (bahwa bila ada nasabah yang mengajukan pembiayaan minuman keras kepada bank dengan akad Murabahah, maka walaupun akadnya sah tetapi transaksi ini haram karena obyek transaksinya haram.

Berdasarkan informasi yang didapatkan dari narasumber, bahwasanya Perusahaan $\mathrm{X}$ menjual minuman keras dan memabukkan yang ternyata sudah terdaftar di Kemendagri, dalam artian penjualan itu sah dan dilindungi oleh badan hukum yang berwenang. Tetapi jika ditinjau dalam hukum Islam, konsep penjualan produk waralaba Perusahaan X minuman keras diharamkan dalam syariat karena sudah masuk ranah khamar. Ayat yang menyatakan haramnya khomr secara mutlaq

\footnotetext{
${ }^{16} \mathrm{Al}$ Juhaily, Al Fiqh Al Islami Wa Adillatuhu.

${ }^{17}$ Hamzah Ya'qub, Kode Etik Dagang Menurut Islam, 1st ed. (Bandung: Diponegoro, 1984).

${ }^{18}$ Adiwarman Azwar Karim, Sejarah Pemikiran Islam, 1st ed. (Jakarta: IIIT Indonesia, 2001).
} 
dan jelas, sedikit atau banyak, waktu sholat atau di luar sholat. Yaitu terdapat dalam QS. Al-Maidah/5:90,

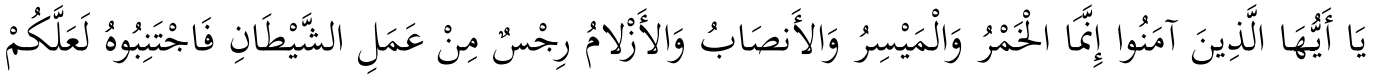

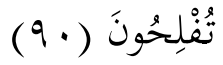

Terjemahannya:

Hai orang-orang yang beriman, sesungguhnya (meminum) khamar, berjudi, (berkorban untuk) berhala, mengundi nasib dengan panah, adalah perbuatan keji termasuk perbuatan syaitan. Maka jauhilah perbuatan-perbuatan itu agar kamu mendapat keberuntungan.

Dari Taisir al-Karim al-Rahman fi Taisir al-Kalam al-Manan yang ditulis oleh Syaikh Abdurrahman bin Nashir as-Sa'di, maka tafsir dari ayat di atas adalah:

Keberuntungan tidak diraih kecuali dengan meninggalkan apa yang dilarang oleh Allah swt. khususnya perbuatan-perbuatan buruk yang disebutkan. Ia adalah khamar, yaitu semua yang merusak akal dengan menutupinya karena mabuk, judi (semua permainan yang memiliki bayaran dari kedua belah pihak seperti taruhan dan semacamnya). Berhala, yaitu sesembahan dan tandingan dan semacamnya yang diangkat dan disembah selain Allah, dan anak panah yang dengannya mereka mengundi nasib, Allah melarang empat perkara ini, mencercanya, dan menjelaskan dampak negatif yang menuntut untuk meninggalkannya. ${ }^{19}$

Sedangkan Perusahaan $\mathrm{Y}$ jika dibandingkan dengan Perusahaan $\mathrm{X}$, tidak menjual barang-barang yang diharamkan, dalam artian semua produk sudah dilegalisasi kehalalannya oleh MUI dan hal ini dianggap sah dalam hukum Islam.

\section{Royalty Fee}

Dalam sebuah hubungan kerjasama fee merupakan sebuah faktor yang paling essensial atau dominan yang memungkinkan seseorang mau bekerja untuk kepentingan bersama, tanpa adanya fee mungkin tidak akan terjalin hubungan kerjasama. Dalam islam dikenal dengan ujrah, ujrah merupakan imbalan dari pemberi kerja kepada penerima kerja untuk sesuatu pekerjaan atau jasa yang telah ada dan akan dilakukan, berlangsung sebagai jaminan kelangsungan yang layak bagi kemanusiaan dan suatu produksi. ${ }^{20}$ Dalam penentuan ujrah (upah) kedua belah pihak harus bersikap jujur dan adil dalam semua urusan agar tidak terjadi tindakan aniaya terhadap orang lain juga tidak merugikan diri sendiri. Oleh karena itu Al-Quran memerintahkan kepada pemberi kerja untuk membayar pekerja dengan bagian yang

\footnotetext{
${ }^{19}$ Abdurrahman bin Nashir As Sa'di, Taisir Al Karim Al Rahman Fi Taisir Al Kalam Al Manan, VI (Jakarta: Darul haq, 2016).

${ }^{20}$ Haeidjarachman Ranupandjojo, Manjemen Personalia (Yogyakarta: BPEF-UGM, 1990).
} 
seharusnya mereka terima sesuai kerja mereka dan pada saat yang sama dia telah menyelamatkan kepentingannya sendiri. ${ }^{21}$

Seperti yang dijelaskan sebelumnya, waralaba memiliki beberapa jenis akad dalam fikih muamalah, salahsatunya yang ditinjau dari royalty fee atau bagi hasil. Waralaba menggunakan sistem bagi hasil mudharabah dalam hal keuntungan dan kerugian baik pihak pemberi waralaba maupun penerima waralaba.

Para imam madzhab sepakat bahwa hukum mudharabah adalah boleh, walaupun di dalam Al-Qur'an tidak secara khusus menyebutkan tentang mudharabah dan lebih mencerminkan anjuran untuk melakukan usaha, dalam QS. AlMuzammil/73: 20

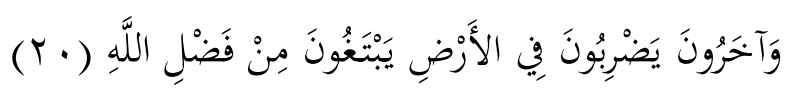

Terjemahannya:

Dan orang-orang yang berjalan di muka bumi mencari sebagian karunia Allah ${ }^{22}$

Diantara hadits yang berkaitan dengan mudharabah adalah hadits yang diriwayatkan oleh Ibn Majah dari Shuhaib.

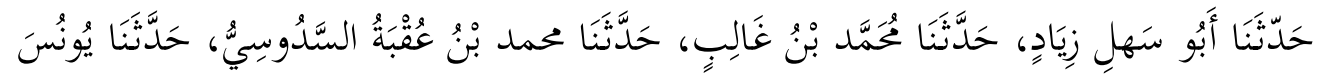

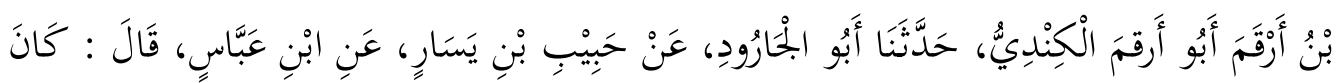

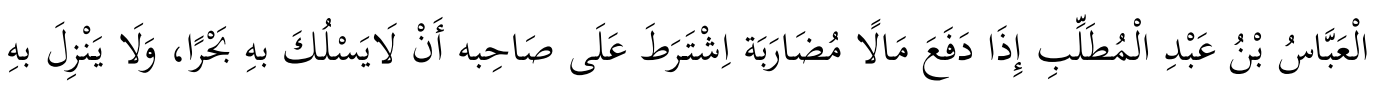

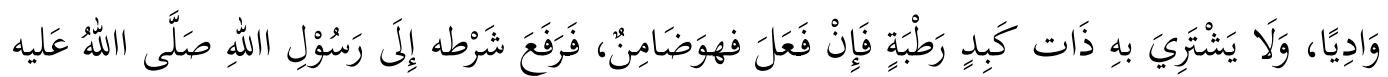

$$
\begin{aligned}
& 23 \text { وَآله وسلم فَأَجَازهُ (رواه الدار قطني) }
\end{aligned}
$$

Artinya:

Abbas bin Abdul Muthallib jika menyerahkan harta sebagai mudharabah, ia mensyaratkan kepada mudharibnya agar tidak mengarungi lautan dan tidak menuruni lembah, serta tidak membeli hewan ternak, jika persyaratan itu dilanggar, ia (mudharib) harus menanggung resikonya. Ketika persyaratan yang ditetapkan Abbas itu didengar Rasulullah, beliau membenarkannya (HR. Ad-Darulquthni).

Dalam Kompilasi Hukum Ekonomi Syariah, ada beberapa ketentuan terkait sistem bagi hasil mudharabah, di antaranya:

Pasal 242

(1) Mudharib berhak atas keuntungan sebagai imbalan pekerjaannya yang disepakati dalam akad

(2) Mudharib tidak berhak mendapatkan imbalan jika usaha yang dilakukan rugi

Pasal 243

\footnotetext{
${ }^{21}$ Afjalur Rahman, Doktri Ekonomi Islam (Jakarta: Dana Bakti Wakaf, 1995).

${ }^{22}$ Departemen Agama RI, Al-Qur'an dan Terjemahnya (Bandung : CV Penerbit J-ART, 2005).

${ }^{23}$ Al-Imam Al Hafizh Ali bin Umar, Sunan Ad-Daraquthni (Jakarta : Pustaka Azzam, 2008).
} 
(1) Pemilik modal berhak atas keuntungan berdasarkan modalnya yang disepakati dalam akad

(2) Pemilik modal tidak berhak mendapatkan keuntungan jika usaha yang dilakukan oleh mudharib merugi

Pasal 246

(1) Keuntungan bagi hasil usaha yang menggunakan modal campuran atau pemilik modal dengan mudharib, dibagi secara proporsional atau atas dasar kesepakatan semua pihak. $^{24}$

Dalam menentukan proporsi keuntungan terdapat beberapa pendapat dari para ahli hukum Islam sebagai berikut:

(1) Imam Malik dan Imam Syafi'i berpendapat bahwa proporsi keuntungan dibagi di antara mereka menurut kesepakatan yang ditentukan sebelumnya dalam akad sesuai dengan proporsi modal yang disertakan

(2) Imam Ahmad berpendapat bahwa proporsi keuntungan dapat pula berbeda dari proporsi modal yang mereka sertakan

(3) Imam Abu Hanifah, yang dapat dikatakan sebagai pendapat tengah-tengah, berpendapat bahwa proporsi keuntungan dapat berbeda dari proporsi modal pada kondisi normal. Namun demikian, mitra yang memutuskan menjadi sleeping partner, proporsi keuntungannya tidak boleh melebihi proporsi modalnya. ${ }^{25}$

Menelaah dari penentuan proporsi keuntungan, maka waralaba toko ritel Perusahaan X dan Perusahaan Y merujuk pada pendapat Imam Malik dan Imam Syafi'i, yakni proporsi keuntungan sudah disepakati sebelumnya sebelum melakukan penandatanganan perjanjian dalam bentuk persentasi diambil dari hasil penjualan.

Analisis Hukum Ekonomi Syariah terhadap Royalty Fee Bisnis Waralaba Toko Ritel Perusahaan X dan Perusahaan Y

\begin{tabular}{|c|c|}
\hline \multicolumn{2}{|c|}{ Royalty Fee } \\
\hline Perusahaan X dan franchisee-nya & Perusahaan Y dan franchisee-nya \\
\hline $3,5 \%$ (Royalti 2,5\% + Pemasaran 1\%) & $2 \%$ \\
\hline
\end{tabular}

\section{Perusahaan $X$}

Pertama, transaksi bagi hasil. Perusahaan $\mathrm{X}$ dengan sistem setiap bulan penerima waralaba harus menyetor royalty fee dan management fee sebesar 3,5\% melalui virtual account. Keterlambatan pembayaran royalty fee diberikan kebijakan sebanyak tiga-enam bulan secara berturut-turut dengan memberikan penangguhan tambahan bunga setiap bulannya, hal ini dikarenakan seperti pengelolaan toko dalam bentuk pemasaran tetap berjalan dari pihak Perusahaan X pusat walaupun penerima waralaba belum sanggup membayarnya. Menurut analisis peneliti merujuk pada

\footnotetext{
${ }^{24}$ Mardani, Fiqh Ekonomi Syariah.

${ }^{25}$ Ascarya, Akad Dan Produk Perbankan SYariah (Jakarta: Rajawali Press, 2007).
} 
konsensus para fuqaha tanpa kecuali, bunga tergolong riba, terlebih lagi lembagalembaga Islam internasional maupun nasional ${ }^{26}$ telah memutuskan sejak tahun 1965 bahwa bunga bank atau sejenisnya adalah sama dan haram secara syariah. Dalil yang menyebutkan bahwa bunga diqiyaskan dengan riba ada pada QS. Ar-Rum/30: 39
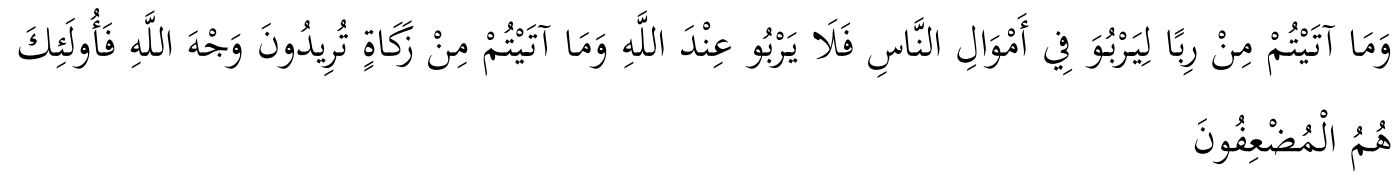

Terjemahannya:

Dan sesuatu riba (tambahan) yang kamu berikan agar dia bertambah pada harta manusia, maka riba itu tidak menambah pada sisi Allah. Dan apa vang kamu berikan berupa zakat yang kamu maksudkan untuk mencapai keridhaan Allah, maka (vang berbuat demikian) itulah orang-orang yang melipat gandakan (pahalanya).

Pandangan ini sesuai dengan penjelasan Syaikh Sholih bin Ghonim As Sadlan. Beliau menjelaskan dalam kitab fiqihnya yang berjudul "Taysir Al Fiqh", seorang Mufti Saudi Arabia bernama Syaikh Muhammad bin Ibrahim rahimahullah mengemukakan bahwa pinjaman yang diberikan oleh bank dengan tambahan (bunga) tertentu sama-sama disebut riba. Secara hakikat, walaupun pihak bank menamakan hal itu qord (utang piutang), namun senyatanya bukan qord. Karena utang piutang dimaksudkan untuk tolong menolong dan berbuat baik. Transaksinya murni non komersial. Bentuknya adalah meminjamkan uang dan akan diganti beberapa waktu kemudian. Bunga bank itu sendiri adalah keuntungan dari transaksi pinjam meminjam. Oleh karena itu yang namanya bunga bank yang diambil dari pinjammeminjam atau simpanan, itu adalah riba karena didapat dari penambahan (dalam utang piutang). Maka keuntungan dalam pinjaman dan simpanan boleh sama-sama disebut riba. ${ }^{27}$ Namun dalam kasus ini, Perusahaan $\mathrm{X}$ tidak memberatkan dalam hal sistem bunga yang harus dibayar karena target waktunya hanya tiga-enam bulan saja, selanjutnya lewat tiga-enam bulan dalam hal ini Perusahaan X akan mengambil tindakan selanjutnya untuk diproses lebih lanjut baik pengakhiran perjanjian waralaba ataupun pengalihan franchisee. Tetapi, besar atau kecilnya bunga, sesuai dengan dalil al-Qur'an dan Sunnah serta kesepakatan para ulama, bunga atau suatu tambahan dari pinjaman atau penangguhan pembayaran tetap dinamakan riba walaupun ada beberapa ulama yang mengatakan bunga itu bukan riba.

Kedua, Pengelolaan toko yang berpengaruh dengan royalty fee dan kaitannya dengan gharar, maisir, dan tadlis seperti pelayanan promosi produk, pembelian produk yang berkala, harga jual produk, logistik dan service. Perusahaan X, royalty fee didapatkan dari hasil penjualan barang dagang tiap outlet dan pelayanan marketing produk (mulai dari promosi, harga diskon, dan lain-lain). Adapun

\footnotetext{
${ }^{26}$ Ascarya, Akad Dan Produk Bank Syariah, VI (Jakarta: PT. Raja Grafindo Persada, 2017).

${ }^{27}$ Sholih bin Ghonim As Sadhlan, Taysir Al Fiqh (Daar Blancia, 1424).
} 
keuntungan yang didapatkan dari hasil penjualan digunakan untuk pembelian produk di pusat, biaya pemeliharaan toko, pajak, dan gaji karyawan. Setelah semuanya terbagi rata, maka keuntungan bersih tersebut barulah disetor dalam bentuk persentase 3,5\% ke franchisor (Pihak Perusahaan X). Nominal penyetoran royalty fee tergantung dari keuntungan bersih, jadi jika omzet penjualan sedikit, maka royalty fee yang didapatkan franchisor juga sedikit. Sistem pembelian produk untuk menunjang peningkatan hasil penjualan juga harus dari standar operasional Perusahaan $\mathrm{X}$ dalam artian pembelian bahan baku harus dari pergudangan Perusahaan X.

Menurut Erwandi Tirmizi dalam bukunya Harta Haram Kontemporer bahwasanya berdasarkan kaidah umum dalam muamalat bahwa pada dasarnya setiap persyaratan itu dibolehkan selagi tidak bertentangan dengan syariat, juga ada manfaat bagi franchisor dalam hal ini guna melariskan produknya dan penguasaan pasar untuk produknya. Pihak franchisee tidak boleh menjual produk selain produk pihak franchisor, ini persyaratan penting dalam akad waralaba yang bertujuan agar pihak franchisor tidak memiliki pesaing produknya. Maka persyaratan ini sangat dibutuhkan oleh franchisor. Dan hukum asalnya setiap persyaratan yang tidak bertentangan dengan Nash dan kemaslahatan adalah dibolehkan. Selain jenis bahan baku yang dibelikan, sistem penyetoran dana untuk pembelian produk juga sangat transparansi, yakni setiap seminggu sekali franchisor atau pemberi waralaba akan menerbitkan faktur tagihan kepada penerima waralaba atas seluruh pembelian produk yang dilakukan pada periode sebelumnya. Pembayaran atas pembelian produk secara rutin tersebut wajib dilakukan oleh penerima waralaba kepada pemberi waralaba dalam jangka waktu minimal tujuh hari setelah diterbitkannya faktur tagihan. Sejauh ini, sesuai dengan analisis peneliti, transparansi antar pemberi waralaba dan penerima waralaba sangat jelas, jadi minim kemungkinan untuk terhindar dari gharar. Begitu pula penentuan harga produk yang dijual kembali setiap outlet, semuanya sudah ditentukan oleh Perusahaan $\mathrm{X}$ melalui screening system, untuk tambahan dengan maksud menambah keuntungan juga sudah dibicarakan secara transparansi baik pemberi waralaba maupun penerima waralaba, narasumber menjelaskan, sejauh ini tidak unsur penipuan atau maisir dalam menaikkan harga produk tanpa sepengetahuan Perusahaan X demi mendapatkan keuntungan dua kali lipat dengan tujuan memudahkan pembayaran royalty fee. Cuman ada hal yang masih perlu dianalisis di antaranya, penjualan produk-produk yang dikategorikan tidak sesuai dengan syariat Islam dilegalkan Perusahaan $\mathrm{X}$ pada umumnya karena mengingat brand ini berasal dari Amerika Serikat, sedangkan segala dagangan yang diperjualbelikan jika masuk dalam kategori tidak sesuai syariat maka jual beli tidak sah dalam kacamata hukum Islam. Sesuai dengan QS. Al-Maidah/5:90, 


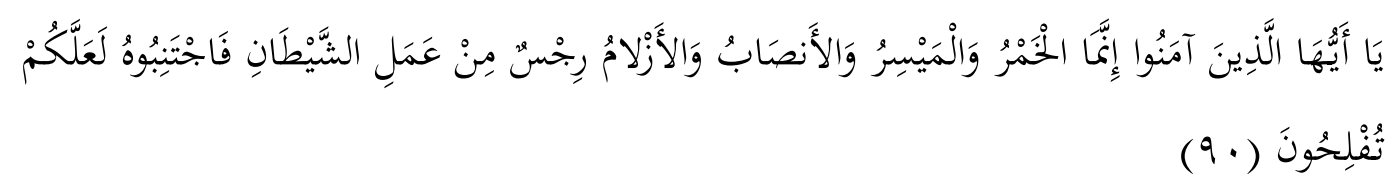

Terjemahannya:

Hai orang-orang yang beriman, sesungguhnya (meminum) khamar, berjudi, (berkorban untuk) berhala, mengundi nasib dengan panah, adalah perbuatan keji termasuk perbuatan syaitan. Maka jauhilah perbuatan-perbuatan itu agar kamu mendapat keberuntungan.

\section{Perusahaan $\mathbf{Y}$}

Pertama, Transaksi bagi hasil. Antara Perusahaan Y dan franchisee-nya, sistem transaksi royalty fee berbeda dibanding waralaba Perusahaan X, yakni melalui cashback, franchisee membeli produk atau barang dagangan ke Perusahaan Y, dari pembelian itu akan ada pengembalian uang dalam bentuk deposit melalui virtual account, selanjutnya dari cashback itulah Perusahaan Y mengambil royalty fee setiap awal bulan. Menurut penjelasan narasumber dari pihak franchisee-nya selama pengambilan royalty fee dari cashback tersebut, tidak pernah melibatkan sistem bunga atau biaya tambahan. Jadi, kesimpulan yang bisa dianalisis oleh peneliti adalah, transaksi bagi hasil ini diperbolehkan dalam syariat hukum Islam karena tidak melibatkan biaya tambahan serta porsi dari royalty fee sudah sesuai dengan yang tertera pada amandemen khusus yang disusun oleh franchisee-nya. Selain itu selama kerjasama dengan Perusahaan Y sangat kecil kemungkinan untuk terlambat melakukan pembayaran royalty fee karena franchisee-nya mendapatkan cashback setiap bulan.

Kedua, Pengelolaan toko yang berpengaruh dengan royalty fee dan kaitannya dengan gharar, maisir, dan tadlis seperti pelayanan promosi produk, pembelian produk yang berkala, harga jual produk, logistik dan service. Antara Perusahaan Y dan franchisee-nya, royalty fee didapatkan dari potongan cashback yang diberikan Perusahaan Y kepada franchisee-nya. Adapun cashback didapatkan dari pembelian produk ke toko Indogrosir cabang Makassar yang nantinya dari pembelian produk itu ada pemotongan harga dan bonus yang diberikan untuk franchisee-nya, dari bonus tersebut, maka pihak Perusahaan Y berhak memotong sebagai iuran wajib atau royalty fee setiap bulannya. Dari segi kerelaan, kedua belah pihak sudah menyetujui, adapun jika pemberian cashback dan potongannya sebagai royalty fee jika dianalisis dalam hukum Islam adalah sesuatu yang diperbolehkan selama tidak mengandung unsur tambahan dan ada transparansi antara kedua belah pihak dalam segi nominal, waktu, dan tempat transaksinya. Jika dikorelasikan dengan Perusahaan Y dan franchisee-nya, maka sejauh ini sudah dalam garis syariat. Di sisi lain, dari pembelian yang dikategorikan bersyarat, sistem Perusahaan Y secara keseluruhan mewajibkan pembelian produk secara berkala setiap bulan, baik ketika stok tersedia 
maupun sudah kehabisan. Sistemnya adalah franchisee-nya memesan produk dan melakukan transaksi pembayaran terlebih dahulu, selanjutnya pihak Perusahaan Y akan mengantarkan barang tersebut ke toko franchisee-nya sesuai dengan waktu yang disepakati, jika dianalisis dalam hukum Islam maka ini sama dengan bay'u alsalam (jual beli dengan pesanan) dan hal ini diperbolehkan dalam syariat selama semuanya dalam unsur yang jelas sesuai dalam Q.S. al-Baqarah/2:282. ${ }^{28}$ Harga produk yang ditetapkan Perusahaan $\mathrm{Y}$ berbeda dengan Perusahaan X, karena Perusahaan $\mathrm{Y}$ adalah waralaba yang fleksibilitasnya lebih dominan seperti penamaan toko sendiri, maka Perusahaan Y juga memberikan keluasan dalam menentukan harga produk dengan syarat memberikan kisaran nominal minimal sampai maksimal selanjutnya franchisee-nya bebas menentukan harga tersebut, selama nominal harga tidak melampaui batas dan merugikan konsumen.

\section{KESIMPULAN}

Berdasarkan hasil penelitian, penerapan waralaba secara global ditinjau dari perspektif hukum ekonomi syariah bahwasanya Waralaba Perusahaan X yakni akad, perjanjian, dan sistemnya sudah sah karena dilakukan secara terbuka atau transparansi, tanpa ada unsur gharar dan penipuan di dalamnya. Sejauh ini pembukaan Perusahaan X, tidak memiliki masalah yang terjadi ketika melakukan proses pembukaan outlet baru dalam artian semua penerima waralaba telah sepakat mengikuti aturan bisnis waralaba ini. Dalam hukum ekonomi syariah, hal ini diperbolehkan, namun, ada hal yang sedikit ditelisik dalam mengenai objek produk yang diperjualbelikan, Perusahaan $\mathrm{X}$ menjual minuman keras, yang mana dalam hukum ekonomi syariah diqiyaskan dengan khamar, dan khamar diharamkan berdasarkan dalil al-Qur'an dan Sunnah.Waralaba Perusahaan Y secara umumnya dengan berbagai toko mitra kerjasama pun juga persis dengan analisis Perusahaan $X$ akad, perjanjian, dan sistemnya sudah sesuai dengan syariat. Adapun Perusahaan $\mathrm{Y}$ dengan franchisee-nya, kedua belah pihak yang melakukan mitra kerjasama memiliki sedikit perbedaan persepsi dari akad dan perjanjian kerjasamanya yang menimbulkan ketidakrelaan dari salah satu pihak, tetapi setelah melakukan musyawarah maka perjanjian kerjasamanya tetap berlanjut dengan gabungan antara sistem Perusahaan Y dan kebijakan khusus dari franchisee-nya.

Pengamatan peneliti untuk ketiga toko dari sistem royalty fee-nya, dapat ditinjau dari berbagai aspek, di antaranya: Pertama, prinsip keadilan. Perusahaan X, para franchisee yang ingin mengajukan kerjasama sudah menyetujui sistem royalty fee yang berlaku di Perusahaan X, tanpa ada unsur paksaan atau keberatan. Maka akad perjanjian pembayaran royalty fee jika dipandang syariat hukum Islam maka dianggap sah. Selanjutnya keterbukaan atau transparansi komunikasi sangat

${ }^{28}$ Shalih Al Fauzan, Al Mulakhasul Fiqh, ed. Abdul Hayyi Al Kattani (Depok: Gema Insani, 2006). 
dikedepankan terkait mitra kerjasama tersebut. Kedua, Perusahaan Y, untuk pengajuan kesepakatan royalty fee, franchisee-nya membuat amandemen khusus terkait itu, meski ada beberapa kendala internal yang terjadi kedua belah pihak, akad kerjasama tetap berjalan, menurut analisis hukum ekonomi syariah masih dikategorikan tidak sesuai dengan syariat Islam karena masuk kategori akad ghairu shahih fasid. Kedua, muamalah terlarang (Riba, Maisir, Gharar, dan Tadlis). Waralaba dari Perusahaan X jika ditinjau dari segi transaksinya, sebenarnya tidak ada permasalahan jika membayar tepat waktu, akan tetapi ketika terjadinya keterlambatan pembayaran royalty fee maka akan dikenakan penambahan pembayaran dari penangguhan waktu selama tiga bulan berturut-turut dan hal ini jika ditelisik mengandung unsur riba. Untuk pembelian, pelayanan, dan suplai produk yang berpengaruh pada pembagian royalty fee semuanya sudah sesuai dengan syariat dalam artian belum ditemukannya unsur maisir, gharar, dan tadlis. Kedua, Perusahaan Y, royalty fee didapatkan dari potongan cashback yang diberikan Perusahaan Y kepada franchisee-nya. Adapun cashback didapatkan dari pembelian produk ke Perusahaan Y yang nantinya dari pembelian produk itu ada pemotongan harga dan bonus yang diberikan untuk franchisee-nya, dari bonus tersebut, maka pihak Perusahaan Y berhak memotong sebagai iuran wajib atau royalty fee setiap bulannya. Dari segi kerelaan, kedua belah pihak sudah menyetujui dan pembagian sistem royalty fee tersebut sudah sesuai dengan kesepakatan kedua belah pihak, adapun jika pemberian cashback dan potongannya sebagai royalty fee jika dianalisis dalam hukum Islam adalah sesuatu yang diperbolehkan selama tidak mengandung unsur tambahan dan ada transparansi antara kedua belah pihak dalam segi nominal, waktu, dan tempat transaksinya.

\section{DAFTAR PUSTAKA}

Abdul Baqi, Muhammad Fu'ad. Mutiara Hadis Yang Disepakati Bukhari Muslim (Al Lu'lu' Wal Marjan). Surabaya: PT. Bina Ilmu, 2005.

Agus Riswadi, Budi. Hak Kekayaan Intelektual Dan Budaya Hukum. Jakarta: PT. Raja Grafindo Persada, 2004.

Alu Syeikh, Abdullah bin Muhammad bin Abdurrahman bin Ishaq. Lubaabut Tafsir Min Ibni Katsir. Pustaka Imam Asy Syafi'i, 2012.

As Sa'di, Abdurrahman bin Nashir. Taisir Al Karim Al Rahman Fi Taisir Al Kalam Al Manan. VI. Jakarta: Darul haq, 2016.

As Sadhlan, Sholih bin Ghonim. Taysir Al Fiqh. Daar Blancia, 1424.

Ascarya. Akad Dan Produk Bank Syariah. VI. Jakarta: PT. Raja Grafindo Persada, 2017.

—. Akad Dan Produk Perbankan SYariah. Jakarta: Rajawali Press, 2007. Bugha, Musthafa Dib Al. Fikih Islam Lengkap Penjelasan Hukum-Hukum Islam Madzhab Syafi'i. Media Zikir, 2010.

Dewi, Gemala. Hukum Perikatan Islam Di Indonesia. V. Jakarta: Kencana, 2018. 
Fauzan, Shalih Al. Al Mulakhasul Fiqh. Edited by Abdul Hayyi Al Kattani. Depok: Gema Insani, 2006.

Hari Yudanto, Oktofan. “Analisis Perjanjian Usaha Waralaba Makanan Dalam Perspektif Hukum Islam (Studi Kasus Di Crunchy Molen Kress Di Desa Gumpang. Kec. Kartasura, Kab. Sukoharjo).” Publikasi Ilmiah, 2017.

Juhaily, Wahbah Al. Al Figh Al Islami Wa Adillatuhu. Beirut: Daar Al Fikr, 1989.

Karim, Adiwarman Azwar. Sejarah Pemikiran Islam. 1st ed. Jakarta: IIIT Indonesia, 2001.

Mardani. Fiqh Ekonomi Syariah. Jakarta: Kencana, 2013. Hukum Bisnis Syariah. Jakarta: Prenada Media Group, 2014.

Najma, Siti. Bisnis Syariah Dari Nol; Langkah Jitu Menuju Kaya, Penuh Berkah Dan Bermakna. Jakarta: Hikmah, 2008.

Odop, Nistains. Berbisnis Waralaba Murah. Yogyakarta: Media Pressindo, 2006.

Rahman, Afjalur. Doktri Ekonomi Islam. Jakarta: Dana Bakti Wakaf, 1995.

Ranupandjojo, Haeidjarachman. Manjemen Personalia. Yogyakarta: BPEF-UGM, 1990.

Remi Sjahdeni, Sutan. Perbankan Syariah: Produk-Produk Dan Aspek-Aspek Hukumnya. 1st ed. Jakarta: Kencana, 2014.

Rohim Faqih, Aunur. "Kontrak Bisnis Syariah Studi Mengenai Penerapan PrinsipPrinsip SYari'ah Dalam Pembiayaan Pada Bank Syariah Di Indonesia,” 2014, 3. Syeikh, Abdullah bin Muhammad bin Abdurrahman bin Ishaq Al. Tafsir Ibnu Katsir Jilid 2. Bogor: Pustaka Imam Syafi'i, 2003.

Ya'qub, Hamzah. Kode Etik Dagang Menurut Islam. 1st ed. Bandung: Diponegoro, 1984. 